\title{
(Un)beliveable wages? An analysis of minimum wage policies in Europe from a living wage perspective
}

\author{
Brian Fabo ${ }^{1,2,3^{*}}$ (D) and Sharon Sarah Belli ${ }^{4}$
}

\author{
* Correspondence: \\ fabob@spp.ceu.edu \\ ${ }^{1}$ School of Public Policy, Nádor u. 9, \\ Budapest 1051, Hungary \\ ${ }^{2}$ Centre for European Policy Studies \\ (CEPS), Brussels, Belgium \\ Full list of author information is \\ available at the end of the article
}

\begin{abstract}
Minimum wage is one of the most debated issues in the labour policy area. Often perceived as a trade-off between employment and equality in earnings, the debate on minimum wage is highly polarized. With regard to the undergoing discussions on the Social Pillar of the European integration, we aim to extend the debate to include the aspect of minimum living standards, by empirically showing the gap between minimum wages and the minimum living wages in the peripheral countries of the European Union.
\end{abstract}

JEL Classification: J39

Keywords: Living wage, Minimum wage, EU Social Pillar

\section{Introduction}

In the 2016 State of the Union, Jean-Claude Juncker, the President of the European Commission, called for increased efforts towards construction of the European Pillar of Social Rights, stressing that Europe was not social enough and it needed a change in that respect (European Commission 2016). Building upon this topic, in January 2017, President Juncker conceptualized his earlier statement specifically within the framework of the minimum wage policy, stressing that while all member states are free to set the minimum wage in line with the local conditions, "There is a level of dignity we have to respect" (Guarascio 2017). Such calls have been reflected also in the demands of the European citizens (Maselli 2016). In this paper, we would like to contribute to the debate started by President Juncker by attributing a monetary value to the notion of the "minimum level of dignity" for the individual EU countries and asses the scope for adjustments needed to achieve this aim.

Societies struggle to find agreement on minimum wage (MW) policies, because of the assorted distributive effects. Economic literature on MW (Cahuc and Zylberberg 2004; Borjas 2015) and empirical research on the topic (Adams and Neumark 2005; Neumark 2014) by and large agree that while raising MW increases wages of lowincome workers in particular, it also results in companies laying off workers (with low-income workers again being among the first to be fired) and decline in economic output. ${ }^{1}$ The great ideological, institutional and political differences between the European Union (EU) member states result in the lack of consistence in setting minimum

(c) The Author(s). 2017 Open Access This article is distributed under the terms of the Creative Commons Attribution 4.0 International License (http://creativecommons.org/licenses/by/4.0/), which permits unrestricted use, distribution, and reproduction in any medium, provided you give appropriate credit to the original author(s) and the source, provide a link to the Creative Commons license, and indicate if changes were made. 
wages in Europe. Some societies are more willing to safeguard growth and employment, while others are more concerned about equality.

The struggle between different ideologies on the topic of MW policies is a healthy manifestation of democratic political order, where different values and arguments compete for the support of the public. Nonetheless, it is important to recognize it produces widely different outcomes. The relative minimum wages in the EU vary anywhere between 37 and $62 \%$ of the median wage (Schulten and Müller 2017). While this diversity of outcomes is not a problem by itself, as it represents legitimate outputs of a democratic process, there are robust normative and economic arguments (summarized in the "Literature review" section) which justify placing a base value, which is necessary to safeguard President Juncker's "minimum level of dignity", which we instrumentalize in this paper using the concept of the living wage (LW).

Our main intended contribution is to put an amount in Euro to LW for several European countries so that we can contrast the calculated amount with the national minimum wage. Based on this exercise, we present how several of the member states of the EU currently set the MW beneath the LW level as well as amounts of MW increase, which would be necessary in each of these countries to guarantee the LW at least for all Europeans working full-time. Importantly, in line with the LW literature (Anker 2011), the presented calculations should be understood as "absolute minimum amount needed for a dignified life" and nothing more. Under no circumstances should our number be interpreted as "sufficient" level of MW. On the contrary, as argued above, we fully appreciate the current diversity of approaches to MW as an expression of legitimate democratic will of European peoples and do not argue for any harmonization beyond ensuring that MW in no member state falls under the LW.

The following text consists of four main sections. Firstly, the "Literature review" section summarizes the history of thinking about LW, along with the main arguments behind the concept. Following is the "Data and estimation strategy" section, which presents the underlining reasons for using the WageIndicator Cost of Living survey, details how the LW amounts are calculated and how we approach the comparison with MW. The results of our calculation, along with policy implications, are presented and discussed in the "Results and discussion" section. Finally, the "Conclusions" section contains a succinct summary of the results, discussion of limitations of our approach and policy implications.

\section{Literature review}

The concept of just remuneration for work is as ancient as civilisation itself, being present in the writings of ancient Greeks and Romans, all the world's great religions (in the modern times most notably in the Social Teaching of the Catholic church), classical economics, and the modern concept of Social Rights born with the establishment of the United Nations (Stabile 2009, 2016). Interestingly, in spite of the rich history, the meaning behind the LW concept has mostly been quite stable and straightforward, typically expressed as a wage necessary for survival based on the real cost of living (May 1982; Wills and Linneker 2014). More recently however, there have been attempts to enlarge the definition to include parameters of "decent life", rather than mere survival, such as the capacity to support families, maintain self-respect and be free to participate in the civic life of the country concerned (Glickman 1999; Brenner 2002). At the same 
time, it has been stressed that too comprehensive calculation might result in a LW that is too easy to discredit through competitiveness concerns (Hirsch 2017).

Historically, the concepts of LW and MW were used interchangeably. Nonetheless, after the war, the meanings started to diverge, because workers receiving MW started being reasonably well protected from poverty, which became a problem concentrated among unemployed and underemployed workers (Stigler 1946). Nonetheless, the connection has recently reestablished as MWs started to lose buying power over time and falling under the rational definition of poverty as governments in different countries failed-for ideological or other reasons-to keep the minimum wages in line with living wages (Schenk 2001). Phenomena such as inflation and a rise in labour productivity provide profit opportunities mainly to high-wage workers, while low wages do not profit from increased wealth to a comparable degree (Pollin 2007; Piketty 2014). As a result, a liveable MW became a challenge again.

LW policy can be justified both on normative and economic/social good grounds. From a normative perspective, the argument for living wage is quite straightforward. According to arguably the most influential western concept of justice formulated by John Rawls as "justice as fairness", inequalities are admissible only as long as they do not hurt the worst off in the society (Rawls 1999). From this it follows that a society generating substantial wealth, a condition EU countries fulfil, should provide decent living standards even for low-income workers. In addition to this normative argument, several economic arguments have been put forward in favour of securing decent income levels for low-income workers, including that it contributes to macroeconomic stability, maintenance of effective private demand and high level of employee's satisfaction and productivity. Additional arguments are that in combination with welfare state, low wages lead to outsourcing of externalities on taxpayers, for example when the lowskilled workers are unable to save up sufficient resources for retirement (Stigler 1946; Kaufman 2010). Finally, as stressed by Piketty (2014), extreme forms of inequality are dangerous to democratic society. Sufficient MW as a redistributive policy in its core is one way to address this issue (Freeman 1996).

Politically, the efforts to guarantee LW have been connected mainly with the Englishspeaking world. The first modern LW campaign started in Baltimore, MD, USA, in 1994 through local legislation, following a proposal from a coalition of civil society actors. This campaign was successful and spawned a range of successors across the USA, as well as in the UK, Canada, Australia and New Zealand (Levi et al. 2002; Luce 2004). Interestingly, there has not been much spillover towards the continental Europe. Instead, the concept gained some prominence within the debate about fair incomes in low-income countries, particularly within the context of the Asian garment industry (Luce 2009). Table 1 contains an overview of some examples of LW initiatives.

\section{Data and estimation strategy}

In general, there are two ways of estimating a threshold for minimum income: as some percentage of average income or through LW. This is what is often referred to as standard of living versus the minimum level of resources debate. In general, we have seen a shift in the policy debate from the minimum level of resources measured through a goods basket towards the relative standard of living conceptualization (Atkinson 2003). For example, the social inclusion agenda of the European Union had 
Table 1 Examples of well-known living wage movements

\begin{tabular}{|c|c|}
\hline $\begin{array}{l}\text { Living Wage } \\
\text { Foundation }\end{array}$ & $\begin{array}{l}\text { A British initiative, which sets the living wage rates separately for London and for the } \\
\text { rest of the country. The amount is currently } £ 8.25 \text { per hour outside London and } £ 9.40 \\
\text { per hour in the city. They are calculated according to the real cost of living, including } \\
\text { food, fuel and childcare. } \\
\text { (www.livingwage.org.uk) }\end{array}$ \\
\hline $\begin{array}{l}\text { Harvard Living Wage } \\
\text { Campaign }\end{array}$ & $\begin{array}{l}\text { Setting living wages for Harvard workers since } 1998 \text {. } \\
\text { Starting wages for workers in the union is now } \$ 10.85 \text { per hour, from } \$ 9 \text { under their } \\
\text { previous contract. }\end{array}$ \\
\hline $\begin{array}{l}\text { New York City Living } \\
\text { Wage }\end{array}$ & $\begin{array}{l}\text { Existing legislation defines a living wage in New York City as a minimum of } \$ 10 \text { per } \\
\text { hour with benefits or } \$ 11.50 \text { per hour without benefit. The movement is trying to } \\
\text { pass new legislation implying a living wage equal to } \$ 14.52 \text { per hour for } 1 \text { adult. } \\
\text { According to the Living Wage calculator (livingwage.mit.edu), this amount is } \\
\text { calculated based on the real cost of living, including food, childcare, medical, } \\
\text { housing, transportation and other. } \\
\text { (Website not available anymore) }\end{array}$ \\
\hline Asia Floor Wage & $\begin{array}{l}\text { The Asia Floor Wage launched in } 2009 \text { calculates living wage in PPP\$. Currently, the } \\
\text { Asia Floor Wage is calculated to be PPP\$ 725, including cost of food, housing, } \\
\text { clothing, healthcare (including maternity and child care), education, fuel, transport } \\
\text { and savings. (http://asia.floorwage.org/) }\end{array}$ \\
\hline $\begin{array}{l}\text { Living Wage by } \\
\text { Wagelndicator }\end{array}$ & $\begin{array}{l}\text { An initiative of the global Wagelndicator foundation. The aim of the project at this } \\
\text { moment is to analyse income and food security in } 9 \text { countries of East Africa: } \\
\text { Mozambique, Tanzania, Kenya, Uganda, Rwanda, Burundi, South Sudan, Ethiopia and } \\
\text { Egypt. Despite its regional focus, the calculations are available for a high number of } \\
\text { countries worldwide, as the eventual ambition is to produce a globally comparable } \\
\text { living wage indicator (http://www.wageindicator.org/main/salary/living-wage/ } \\
\text { living-wage-map) }\end{array}$ \\
\hline
\end{tabular}

been based on criteria such as the top/bottom earners ratio or the share of population under the poverty line before and after social transfers (Atkinson et al. 2002). As a result, the shift towards LW heralded by President Juncker represents something new for continental Europe.

A shift towards using the LW as a poverty threshold, however, requires dependable data, which are short in supply outside of the UK, due to embeddedness of the LW debate in the English-speaking world. Consequentially, there are no internationally comparative official calculations of LW available that would cover the EU. The national statistical offices do collect price information to calculating statistical indicators, most prominently inflation. Nonetheless, normally only aggregated price indices are published rather than individual prices necessary to calculate the LW.

Particularly in Central and Eastern Europe, some countries calculate a "subsistence minimum". For example, in Slovakia ${ }^{2}$, it is adjusted annually based on average earnings and prices of a basket of items consumed by low-income citizens. Since 2013, it has remained stable at about 200 EUR, about half of the minimum wage amount in the country. The last published amount in neighbouring Hungary, a country with a rather generally lower level of income than Slovakia, valid for 2015, equalled about 290 EUR and was widely considered rather low (Kiss 2015). In another neighbouring country, Czechia $^{3}$, the amount is just about 120 EUR. Given the big differences between amounts in comparable countries and their low value, it is hard to see how these official figures could have been used in an international comparison.

The lack of official data sources is partly filled by several online tools. Perhaps the most famous of these tools is the MIT Billion Prices Project that collects online prices online to estimate price indices in 50 countries since 2008, which have achieved remarkable similarity with the official statistics (Cavallo and Rigobon 2016; Cavallo 2017). 
Nonetheless, this dataset is limited to supermarket prices and as such cannot be used to estimate LW, which necessarily contains items like housing, which are not traded in supermarkets.

Since 2014, the Amsterdam-based WageIndicator Foundation (WI) started collecting prices in nearly 90 countries through online surveys with the specific aim of being able to calculate LW globally (Guzi 2014). The project is based on a number of websites, which contain information about wages and working legislation, in each of the individual countries, visited by about 34 million people on an annual basis (Guzi et al. 2016). Every day, the visitors are asked to report the price of an item picked from a list of items through a banner. Those who click on the banner are then asked to report their location and the price of the "item of the day" and potentially some related items (see Fig. 1). Those who provide this information are further given a long list of items and asked to report the prices of as many items on the list as possible. Where relevant, the respondent can choose to provide price information for different package sizes.

Using the survey, WI collects price data on a continuous basis since 2014. For all items, which have at least ten observations, WI publishes the 25th percentile and median statistic updated twice a year and publishes them online. ${ }^{4}$ Furthermore, WI calculates LW using a methodology rooted in the ILO approach (Anker 2005, 2011). The LW consists of three basis items necessary for life: food, housing and transportation. Food costs are calculated using approximately 50 food items, weighted by item groups based on their consumption in the country as defined by FAO. For housing, apartment rental outside of the city centre is considered. The transportation item is based on a monthly public transportation pass. ${ }^{5}$ A $10 \%$ premium is added to cover other necessities such as clothing, hygienic needs, culture or civic participation. LW is calculated as a range, using the 25th percentile of prices as the lower bound and the median value as the upper bound. Even though the respondents report their precise location, for now, LW is published on the country level. The amounts are published in the national currency and the euro, using the average exchange rate for the 6 months preceding the publication of the data.

WI calculates LW on the individual and family levels. Family is assumed to have two adults (a male and a female) in a productive age and several children depending on a

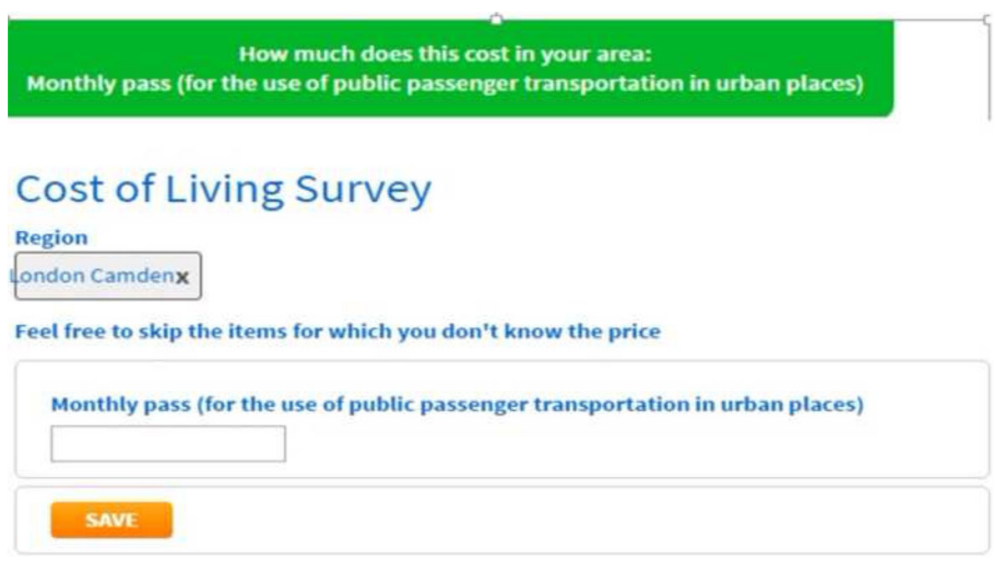

Fig. 1 The banner and the "item of the day" question on the British website for 7th Match 2017. Source: paywizard.co.uk 
fertility rate in the country (in the case of the EU, countries vary between 1.3 and 1.9). For income, the employment rate for men and women in the country is considered (in the case of the EU countries, 1.6-1.8 income is assumed for a family). For an individual, the LW considers a one-room apartment, while for a family, a three-room apartment is deemed appropriate. For transportation purpose, it is assumed the household is located in an urban environment and there is a public transportation system available.

While WI is a valuable source, it is not a representative one, given that respondents are self-selected and the survey is only accessible through the Internet. There is a wide debate in the literature about the merit of such convenience sample-based surveys (Couper 2000; Dillman and Bowker 2001; Bethlehem 2010). A substantial number of empirical experiments with the WI survey generally show that the survey is appropriate for explorative research but not necessary for inferring relationship between variables (de Pedraza et al. 2010; Tijdens and Steinmetz 2016). As such, the WI datasets are increasingly used to particularly study topics which are hard to address using traditional data sources (Besamusca and Tijdens 2015, Guzi and de Pedraza 2015; Tijdens et al. 2015; van Klaveren et al. 2015). The limits and potential of using the WI data, as well as other web-based data sources, have been recently discussed in the IZA Journals Series as well (Mýtna-Kureková et al. 2015; Lenaerts et al. 2016).

We then compare LW with MW in European countries to see if the MW at least covers the minimum requirements for living. MWs are obtained from Eurostat. Unfortunately, we do not see any way to control for the effect of income taxes and social security deductions, given that they depend on many individual-level variables. It has been argued that this is not a major issue as the amounts tend to be quite modest for the low-income segment of the population (Guzi 2014) due to tax credit/personal allowance/zero tax rate threshold policies. Furthermore, people on low incomes tend to benefit more from welfare transfers. Nonetheless, it is likely that if we could take taxes into account, the calculated LW would be slightly higher.

\section{Results and discussion}

Looking at the data, we were able to calculate LW for 14 member states. Those that are missing either do not have a MW (Denmark, Italy, Cyprus, Austria, Finland and Sweden) or there is insufficient data collected so far through the WI survey to calculate the LW (Luxembourg, Malta, Lithuania, Estonia, Latvia, Ireland, Slovenia, Croatia).

The data that are available confirm the major centre-periphery divide (Table 2). In general, life in the core countries is quite expansive but matched with sufficient earnings to cover the needs. Meanwhile, in the periphery, it is not the case and MWs are commonly not sufficient to cover basic needs.

In the Northwestern EU countries (Benelux, Germany, France, UK), even the upper range of LW rarely overcomes $80 \%$ of the MW threshold and the lower threshold can even go below $50 \%$. In other words, in the core countries, MW earners can secure basic living necessities and still have $20-50 \%$ for additional expenses or savings. MW earners can afford to live in relative comfort, even though life in those countries is not cheap-the LW tends to amount to about 1000 EUR or more. Nonetheless, with MW starting at over 1300 EUR in the Netherlands and reaching up to over 1800 EUR in Germany, the MW earners are able to cover their needs. Among the peripheral countries, the upper LW threshold is above MW. 
Table 2 Comparison of living and minimum wage

\begin{tabular}{|r|c|c|c|c|c|c|}
\hline & \multicolumn{3}{|c|}{ Individual income } & \multicolumn{3}{c|}{ Typical family income } \\
\cline { 2 - 7 } & LW & MW & percentage & LW & MW & percentage \\
\hline Belgium & $946-1120$ & 1412 & $67 \%-79 \%$ & $1080-1340$ & 2485 & $39 \%-49 \%$ \\
Bulgaria & $295-392$ & 235 & $126 \%-167 \%$ & $392-511$ & 402 & $95 \%-124 \%$ \\
\hline Czechia & $477-585$ & 407 & $117 \%-144 \%$ & $518-655$ & 733 & $74 \%-94 \%$ \\
France & $855-1060$ & 1458 & $59 \%-73 \%$ & $1100-1370$ & 2581 & $41 \%-51 \%$ \\
\hline Germany & $892-1150$ & 1839 & $49 \%-63 \%$ & $1030-1430$ & 3329 & $39 \%-54 \%$ \\
Greece & $399-475$ & 586 & $68 \%-81 \%$ & $522-623$ & 949 & $42 \%-50 \%$ \\
Hungary & $446-581$ & 412 & $108 \%-141 \%$ & $550-743$ & 700 & $82 \%-111 \%$ \\
Netherlands & $844-1100$ & 1319 & $64 \%-83 \%$ & $900-1200$ & 2387 & $34 \%-45 \%$ \\
Poland & $464-573$ & 429 & $108 \%-134 \%$ & $529-649$ & 738 & $65 \%-79 \%$ \\
Portugal & $496-626$ & 557 & $89 \%-112 \%$ & $596-765$ & 964 & $53 \%-68 \%$ \\
Romania & $329-441$ & 309 & $106 \%-143 \%$ & $410-532$ & 525 & $86 \%-112 \%$ \\
Slovakia & $507-644$ & 435 & $117 \%-148 \%$ & $581-727$ & 748 & $79 \%-98 \%$ \\
Spain & $616-871$ & 655 & $94 \%-133 \%$ & $747-1050$ & 1060 & $53 \%-74 \%$ \\
United Kingdom & $932-1206$ & 1469 & $63 \%-82 \%$ & $1001-1334$ & 2602 & $44 \%-59 \%$ \\
\hline
\end{tabular}

Yellow colour marks countries, for which individual minimum wage is potentially lower than the minimum wage. Red colour denotes those countries, in which even pooled MWs in a family are potentially lower than LW. Source: own calculation based on WI from December 2016. Q1 2017 Eurostat data used for MWs

LW living wage (given as an interval), MW minimum wage, Percentage LW as a percentage of MW

Peripheral countries can be divided to southern (Greece, Spain, Portugal) and eastern (Visegrad countries, Bulgaria and Romania). The southern group treats its MW earners relatively better. The MWs tend to be around 600 EUR, which is enough to cover life LW in Greece and is at a lower threshold of LW in Portugal and Spain. Nonetheless, the MW falls short of covering the upper edge of the LW, particularly in Spain, where LW is slightly higher than in Greece or Portugal. Meanwhile, in the eastern countries, the MW falls 10-60\% short of covering even the lower threshold of the LW. In this group, we identify two distinct subgroups-the Visegrad countries which are similar to southern periphery in terms of living costs, but MW is only about 400 EUR, and Bulgaria/Romania, where LW as well as MW is lower.

The situations improve when looking at the family LW. Here, the lower threshold lies underneath the combined MW of the two adults in the household, and the upper threshold is above the MW in only three countries: Bulgaria, Hungary and Romania.

Looking at the graphical representation of LW and MW, we can see the four clusters quite clearly (Fig. 2). Two things are of note here-the substantial distance between the core and the periphery and the relatively substantial extent to which peripheral countries (other than Greece) must improve to achieve the minimum standard of dignity called for by president Juncker. Such an increase in minimum wage, of course, could potentially have a significant detrimental impact on the competitiveness of those countries, which have based their business model largely on the low-wage model of "embedded neoliberalism" (Bohle and Greskovits 2007, 2012; Greskovits 2015). As such, the 


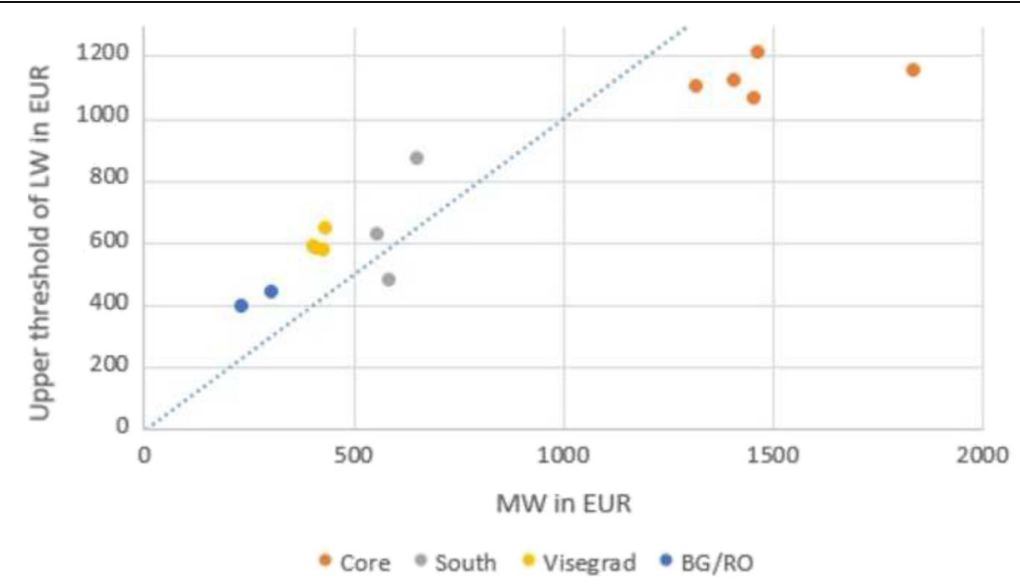

Fig. 2 Graphical distribution of countries based on individual MW and LW. Source: own calculation based on WI from December 2016. Q1 2017 Eurostat data used for MWs

figures presented in this paper relate not only to the minimum wage debate but also the larger debate about "variants of capitalism" in the EU.

As a final point, when looking at the structure of LW per country, we see a degree of variation (Fig. 3). This is particularly the case when housing, as the single biggest parameter in the LW calculation, is concerned. The housing costs appear to form a disproportional share of LW, over $70 \%$ compared to about $65 \%$ in average, in the UK, along with three Visegrad countries: Czechia, Slovakia and Poland. In most countries, The UK balances out expensive housing with high incomes; nonetheless, in the Visegrad countries, this factor certainly contributes to MW insufficiently covering the LW.

The policy implication of our analysis appears quite straightforward. If building a social pillar of the EU integration means a guarantee of minimum level of dignity for all, the MWs in the peripheral countries of the Union need to increase to cover at least the MW. Because MWs in the core countries of the EU generally significantly surpass the LW, a partial degree of convergence is sufficient. In addition, making housing more

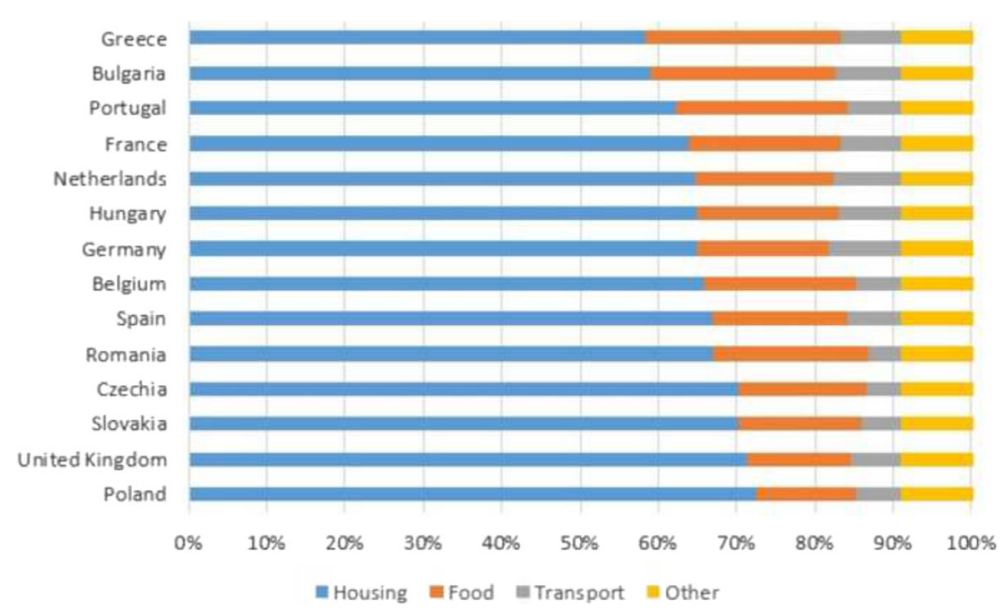

Fig. 3 Relative share of individual items in the lower threshold of LW. Source: own calculation based on WI from December 2016 
accessible to low earners might be an appropriate alternative policy response, particularly in the Visegrad countries. Given that an increased MW will likely cover the costs of basics, such as food and housing, such a policy can be expected to boost domestic demand. Particularly, in the eastern peripheral EU states, with relatively low unemployment rates, the case for MW increase appears to be clear cut.

\section{Conclusions}

The Social Pillar of the EU brings an impetus to think about MW from the perspective of the LW. Making wages "liveable", guaranteeing workers the possibility to pursue basic liberties and reducing wealth and income inequality should be the main priority of EU institutions. In this paper, we present data, which support the claim that a Social Pillar of the EU should entail a hike in MW in the peripheral EU countries. Except for Greece, we found MW in all examined peripheral countries is lower than the LW for individuals and in the case of Hungary, Bulgaria and Romania also for families with more than one earner. In the core EU countries, the MW sufficiently covers the LW.

While our findings are clear in their general message, more work is needed to develop robust indicators of LW compliance in Europe. Firstly, the consumer price data collected by the statistical offices should be used to regularly calculate a LW for all EU member states according to a single methodology. The methodology should probably be more comprehensive than one presented in this paper and take other important costs, such as civic participation into account. It should also consider taxation and social transfer. At the same time, the LW should not be too high, leaving it up to member states to strike the right balance between equality and competitiveness. In this effort, the online-based calculations, such as WI, can provide a useful advance indicator, if they can be benchmarked against an official dataset.

\section{Endnotes}

${ }^{1}$ While this model applies in theory, in some special cases, a modest increase in MW has not had significantly negative impact on employment (Neumark and Wascher 2010).

${ }^{2}$ According to the Slovak Social Insurance Authority (http://www.socpoist.sk/aktualityzivotne-minimum-sa-od-1-jula-2016-opat-nemeni/61733c).

${ }^{3}$ According to the Czech Ministry of Labour and Social Affairs (http://www.mpsv.cz/ cs/11852).

${ }^{4}$ http://wageindicator-wages-in-context.silk.co/

${ }^{5}$ The LW calculation thus assumes the urban environment context for calculation.

\section{Acknowledgements}

The authors are grateful to ETUI Senior Researcher Martin Myant, IZA JoELS editor Martin Kahanec and the anonymous reviewer for useful feedback for the paper. All remaining errors remain the responsibility of the authors.

Responsible editor: Martin Kahanec

\section{Funding}

The authors are grateful to the European Trade Union Institute (ETUI) for financial support towards the production of this paper. Brian Fabo acknowledges the financial support of the Eduworks Marie Curie Initial Training Network Project (PITN-GA-2013-608311) of the European Commission's 7th Framework Programme. 


\section{Competing interests}

The IZA Journal of Labor Policy is committed to the IZA Guiding Principles of Research Integrity. The authors declare that they have observed these principles.

\section{Publisher's Note}

Springer Nature remains neutral with regard to jurisdictional claims in published maps and institutional affiliations.

\section{Author details}

${ }^{1}$ School of Public Policy, Nádor u. 9, Budapest 1051, Hungary. ${ }^{2}$ Centre for European Policy Studies (CEPS), Brussels, Belgium. ${ }^{3}$ Central European Labour Studies Institute (CELSI), Bratislava, Slovakia. ${ }^{4}$ Central European University (CEU), Budapest, Hungary.

Received: 21 November 2016 Accepted: 16 March 2017

Published online: 30 May 2017

\section{References}

Adams S, Neumark D (2005) Living wage effects: new and improved evidence. Econ Dev Q 19:80-102. doi:10.1177/ 0891242404268639

Anker R (2005) A new methodology for estimating internationally comparable poverty lines and living wage rates Anker R (2011) Estimating a living wage: a methodological review. ILO

Atkinson AB (2003) Income inequality in OECD countries: data and explanations. CESifo Econ Stud 49:479-513

Atkinson T, Cantillon B, Marlier E, Nolan B (2002) Social indicators: the EU and social inclusion. OUP, Oxford

Besamusca J, Tijdens K (2015) Comparing collective bargaining agreements for developing countries. Int J Manpow $36: 86-102$

Bethlehem J (2010) Selection bias in web surveys. Int Stat Rev 78:161-188

Bohle D, Greskovits B (2007) Neoliberalism, embedded neoliberalism and neocorporatism: towards transnational capitalism in Central-Eastern Europe. West Eur Polit 30:443-466. doi:10.1080/01402380701276287

Bohle D, Greskovits B (2012) Capitalist diversity on Europe's periphery, 1st edn. Cornell University Press, Ithaca

Borjas G (2015) Labor Economics, 7th edn. McGraw-Hill Education, New York

Brenner M (2002) Defining and measuring a global living wage: theoretical and conceptual issues. In: document établi pour la conférence Global Labor Standards and Living Wages, à I'Université de Massachusetts-Amherst. Citeseer, pp 19-20

Cahuc P, Zylberberg A (2004) Labor economics. The MIT Press, Cambridge

Cavallo A (2017) Are online and offline prices similar? Evidence from large multi-channel retailers. Am Econ Rev 107:283-303. doi:10.1257/aer.20160542

Cavallo A, Rigobon R (2016) The Billion Prices Project: using online prices for measurement and research. J Econ Perspect 30:151-178. doi:10.1257/jep.30.2.151

Couper MP (2000) Review: web surveys: a review of issues and approaches. Public Opin Q 64:464-494

de Pedraza P, Tijdens K, de Bustillo RM, Steinmetz S (2010) A Spanish continuous volunteer web survey: sample bias, weighting and efficiency. Reis Rev Esp Investig Sociológicas 109-130.

Dillman DA, Bowker DK (2001) The web questionnaire challenge to survey methodologists. In: Bemad Batinic, UIfDietrich Reips, Michael Bosnjak \& Andreas Werner: Online Social Sciences. Seattle: Hogrefe \& Huber. pp 53-71.

European Commission (2016) Towards a European Pillar of Social Rights

Freeman RB (1996) The minimum wage as a redistributive tool. Econ J 106:639-649. doi:10.2307/2235571

Glickman LB (1999) A living wage: American workers and the making of consumer society. Cornell University Press, Ithaca

Greskovits B (2015) Ten years of enlargement and the forces of labour in Central and Eastern Europe. Transf Eur Rev Labour Res 21:269-284. doi:10.1177/1024258915585932

Guarascio F (2017) EU states should guarantee minimum income for citizens_Juncker. Reuters. http://uk.reuters.com article/uk-eu-labor-juncker-idUKKBN15729W.

Guzi M (2014) Estimating a living wage globally. Living Ster 59.

Guzi M, de Pedraza P (2015) A web survey analysis of subjective well-being. Int J Manpow 36:48-67. doi:10.1108/IJM12-2014-0237

Guzi M, Kahanec M, Kabina T (2016) Codebook and explanatory note of the Wagelndicator Cost-of-Living Survey and Living Wage calculations. Wagelndicator Foundation, Amsterdam

Hirsch D (2017) The Living Wage in the UK

Kaufman BE (2010) Institutional economics and the minimum wage: broadening the theoretical and policy debate. ILR Rev 63:427-453. doi:10.1177/001979391006300304

Kiss A (2015) Hungary: working poor, minimum wage and minimum income.

Lenaerts K, Beblavý M, Fabo B (2016) Prospects for utilisation of non-vacancy Internet data in labour market analysis—an overview. IZA J Labor Econ 5:1-18. doi:10.1186/s40172-016-0042-z

Levi M, Olson DJ, Steinman E (2002) Living-wage campaigns and laws. WorkingUSA 6:111-132. doi:10.1111/j.1743-4580 $200200009 x-i 1$

Luce S (2004) Fighting for a living wage, 1st edn. ILR Press, Ithaca

Luce S (2009) Raising wages on a regional level: the Asia Floor Wage. Asia Floor Wage Alliance, New Delhi

Maselli I (2016) The social pillar already exists.... Centre for European Policy Studies, Brussels

May M (1982) The historical problem of the family wage: the Ford Motor Company and the Five Dollar Day. Fem Stud 8:399-424. doi:10.2307/3177569

Mýtna-Kureková L, Beblavý M, Thum-Thysen A (2015) Using online vacancies and web surveys to analyse the labour market: a methodological inquiry. IZA J Labor Econ 4:1-20. doi:10.1186/s40172-015-0034-4 
Neumark D (2014) Employment effects of minimum wages. IZA World Labor. doi:10.15185/izawol.6

Neumark D, Wascher WL (2010) Minimum wages, Reprint edition. The MIT Press, Cambridge

Piketty T (2014) Capital in the twenty first century. Belknap, Cambridge

Pollin R (2007) Economic prospects: making the federal minimum wage a living wage. New Labor Forum 16:103-107

Rawls J (1999) A theory of justice, revised edition. Belknap Press, Cambridge, Mass

Schenk CR (2001) From poverty wages to a living wage. CSJ Foundation for Research and Education

Schulten T, Müller T (2017) Minimum wages and living wages in Europe

Stabile DR (2009) The living wage: lessons from the history of economic thought. Edward Elgar Pub, Cheltenham, Northampton

Stabile D (2016) The political economy of a living wage: progressives, the new deal, and social justice. Springer

Stigler GJ (1946) The economics of minimum wage legislation. Am Econ Rev 36:358-365

Tijdens K, Steinmetz S (2016) Is the web a promising tool for data collection in developing countries? An analysis of the sample bias of 10 web and face-to-face surveys from Africa, Asia, and South America. Int J Soc Res Methodol 19:461-479. doi:10.1080/13645579.2015.1035875

Tijdens K, Beblavý M, Thum-Thysen A (2015) Do educational requirements in vacancies match the educational attainments of job holders

van Klaveren, M., Gregory, D., \& Schulten, T. (Eds.). (2015). Minimum wages, collective bargaining and economic development in Asia and Europe: a labour perspective. Springer. http://www.springer.com/de/book/ 9781137512406\#)therversion=9781349506309.

Wills J, Linneker B (2014) In-work poverty and the living wage in the United Kingdom: a geographical perspective. Trans Inst Br Geogr 39:182-194. doi:10.1111/tran.12020

\section{Submit your manuscript to a SpringerOpen ${ }^{\circ}$ journal and benefit from:}

- Convenient online submission

- Rigorous peer review

Open access: articles freely available online

- High visibility within the field

Retaining the copyright to your article

Submit your next manuscript at $\boldsymbol{\triangleright}$ springeropen.com 